\title{
Development of a Kit for Rapid Immunochromatographic Detection of Sacbrood Virus Infecting Apis cerana (AcSBV) Based on Polyclonal and Monoclonal Antibodies Raised against Recombinant VP1 and VP2 Expressed in Escherichia coli
}

\author{
Song Hee Lee ${ }^{1,+}$, Tae-Kyun Oh ${ }^{2,+}$, Sung Oh ${ }^{1}$, Seongdae Kim ${ }^{1}$, Han Byul Noh ${ }^{1}$, Nagarajan Vinod ${ }^{1}$, Ji Yoon Lee ${ }^{1}$, \\ Eun Sun Moon ${ }^{1}$ and Chang Won Choi ${ }^{1, * \text { (I) }}$ \\ 1 Department of Biology \& Medicinal Science, Pai Chai University, Daejeon 35345, Korea; \\ thdgm16245@naver.com (S.H.L.); ohsung85@gmail.com (S.O.); khboy111@pcu.ac.kr (S.K.); \\ creator1018@pcu.ac.kr (H.B.N.); biovinz@gmail.com (N.V.); spunji970@naver.com (J.Y.L.); \\ ansdmstjs124@naver.com (E.S.M.) \\ 2 GeNet Bio Company, Daejeon 305-500, Korea; tkoh@genetbio.co.kr \\ * Correspondence: choicw@pcu.ac.kr; Tel.: +82-42-520-5617 \\ + Song Hee Lee and Tae-Kyun Oh are co-first authors.
}

check for updates

Citation: Lee, S.H.; Oh, T.-K.; Oh, S.; Kim, S.; Noh, H.B.; Vinod, N.; Lee, J.Y.; Moon, E.S.; Choi, C.W. Development of a Kit for Rapid Immunochromatographic Detection of Sacbrood Virus Infecting Apis cerana (AcSBV) Based on Polyclonal and Monoclonal Antibodies Raised against Recombinant VP1 and VP2 Expressed in Escherichia coli. Viruses 2021, 13, 2439. https://doi.org/ $10.3390 /$ v13122439

Academic Editor: Eugene V. Ryabov

Received: 2 November 2021

Accepted: 29 November 2021

Published: 4 December 2021

Publisher's Note: MDPI stays neutral with regard to jurisdictional claims in published maps and institutional affiliations.

Copyright: (c) 2021 by the authors. Licensee MDPI, Basel, Switzerland. This article is an open access article distributed under the terms and conditions of the Creative Commons Attribution (CC BY) license (https:// creativecommons.org/licenses/by/ $4.0 /)$.

\begin{abstract}
A Korean isolate of the sacbrood virus infecting Apis cerana (AcSBV-Kor) is the most destructive honeybee virus, causing serious economic damage losses in Korean apiculture. To address this, here, we attempted to develop an assay for the rapid detection of AcSBV-Kor based on immunochromatographic detection of constituent viral proteins. Genes encoding VP1 and VP2 proteins of AcSBV-Kor were cloned into an expression vector (pET-28a) and expressed in Escherichia coli BL21(DE3). During purification, recombinant VP1 (rVP1) and VP2 (rVP2) proteins were found in the insoluble fraction, with a molecular size of 26.7 and $24.9 \mathrm{kDa}$, respectively. BALB/c mice immunized with the purified rVP1 and rVP2 produced polyclonal antibodies (pAbs) such as pAb-rVP1 and pAb-rVP2. Western blot analysis showed that pAb-rVP1 strongly reacted with the homologous rVP1 but weakly reacted with heterologous rVP2. However, pAb-rVP2 strongly reacted not only with the homologous rVP2 but also with the heterologous rVP1. Spleen cells of the immunized mice fused with SP2/0-Ag14 myeloma cells produced monoclonal antibodies (mAbs) such as mAb-rVP1-1 and mAb-rVP2-13. Western blot analysis indicated that pAb-rVP1, pAb-rVP2, mAb-rVP1-1, and mAb-rVP2-13 reacted with AcSBV-infected honeybees and larvae as well as the corresponding recombinant proteins. These antibodies were then used in the development of a rapid immunochromatography (IC) strip assay kit with colloidal gold coupled to pAb-rVP1 and pAb-rVP2 at the conjugate pad and mAb-rVP1-1 and mAb-rVP2-13 at the test line. One antibody pair, pAb-rVP1/mAb-VP1-1, showed positive reactivity as low as $1.38 \times 10^{3}$ copies, while the other pair, pAb-rVP2/mAb-VP2-13, showed positive reactivity as low as $1.38 \times 10^{4}$ copies. Therefore, the antibody pair pAb-rVP1/mAb-VP1-1 was selected as a final candidate for validation. To validate the detection of AcSBV, the IC strip tests were conducted with 50 positive and 50 negative samples and compared with real-time PCR tests. The results confirm that the developed IC assay is a sufficiently sensitive and specific detection method for user-friendly and rapid detection of AcSBV.
\end{abstract}

Keywords: sacbrood virus infecting Apis cerana (AcSBV); recombinant VP1 (rVP1) and VP2 (rVP2) proteins; polyclonal antibodies (pAb-rVP1 and pAb-rVP2); monoclonal antibodies (mAb-rVP1 and mAb-rVP2); immunochromatography (IC) strip assay

\section{Introduction}

Sacbrood virus (SBV) is one of the most destructive honeybee viruses and it causes economic losses in Asian apiculture [1-7]. Chinese sacbrood virus (CSBV) reemerged in Liaoning Province of China in 2008, devastating the local apiculture [8]. The threat of mass 
extinction of the A. cerana population is an ongoing problem in Korea because the lethal AcSBV-Kor has caused more than 90\% mortality since its first occurrence in 2008 [9-12]. $\mathrm{SBV}$ is a single-stranded, positive-sense RNA ( $\sim 8.8 \mathrm{~kb}$ in size $)$ virus that belongs to the family Iflaviridae [13]. SBV isolates infect Apis cerana (AcSBV) and A. mellifera (AmSBV), each of which represents different serotypes [14-16]. In a previous cross-infection study, AmSBV and AcSBV were shown to be pathogenic only in A. mellifera larvae and A. cerana larvae, respectively [17]. However, a recent study showed that AcSBV could infect $A$. mellifera with low pathogenicity [15], and phylogenetic tree analyses supported cross-infection between AmSBV and AcSBV $[5,7,16,18,19]$.

Four structural proteins in the order VP2-VP4-VP3-VP1 are located at the SBV capsid [19], although the presence of the VP4 protein has yet not been demonstrated [13]. The capsid proteins VP1, VP2, and VP3 are processed from one polyprotein precursor ( $\mathrm{P} 1$ protein) to form a protomer and organized with pseudo-T3 icosahedral symmetry. The VP1 subunits form pentamers positioned around a 5-fold axis, whereas the VP2 and VP3 subunits form hetero-hexamers distributed at the icosahedral 3-fold axis [13,20]. Recently, a Korean isolate of the AcSBV (AcSBV-Kor) was detected using a polyclonal antibody $(\mathrm{pAb})$ raised against the recombinant protein $\mathrm{VP3}(\mathrm{rVP} 3,26.18 \mathrm{kDa})$ expressed in Escherichia coli [21]. In addition, AcSBV was detected from AcSBV-infected honeybees using a monoclonal antibody $(\mathrm{mAb})$ raised against the $\mathrm{rVP} 2$ protein expressed in E. coli [22].

To date, reverse transcriptase polymerase chain reaction (RT-PCR), reverse transcription loop-mediated isothermal amplification (RT-LAMP), and real-time RT-PCR are the most conventional methods for the detection and quantification of the viral genome of beeinfecting viruses [1,9,23-29]. Recently, a next-generation sequencing method was used to discover additional bee-infecting viruses [30]. Nevertheless, these methods cannot rapidly diagnose AcSBV infection in larva and honeybee samples. At present, no user-friendly antigen-antibody-based test kits are available. Therefore, it is necessary to find a target antigen to produce an antibody for the antigen point-of-care testing (POCT) and rapid AcSBV diagnosis.

Over the last few decades, many immunochromatography (IC) assays have been developed to diagnose human or animal infectious diseases [31-37]) and to detect specific markers in the medical [38-40], agricultural, and food industries [41-43]. An IC strip is composed of four components, a sample pad, a conjugate pad, a nitrocellulose membrane, and an absorbent pad [44]. In general, antibody pairs have been used for the IC strip using either a single monoclonal antibody $(\mathrm{mAb})$ [45] or two different $\mathrm{mAbs}$ as detector and capture antibodies $[34,46,47]$. The combination of a mAb and a polyclonal antibody (pAb) as detector and to capture antibodies provided an alternative platform to the sandwich format of IC test [32] and vice versa [41].

In this study, genes encoding VP1 and VP2 proteins of (AcSBV-Kor were cloned into an expression vector (pET-28a) and expressed in Escherichia coli BL21(DE3) for production of the recombinant VP1 (rVP1) and VP2 (rVP2) proteins. BALB/c mice were immunized with the purified rVP1 and rVP2 to produce pAbs and mAbs, respectively. Ultimately, we developed an IC assay using the antibody pair (pAb as detector antibody and $\mathrm{mAb}$ as capture antibody) for the rapid, sensitive, and specific detection of AcSBV in larvae and honeybees collected from a beekeeping farm.

\section{Materials and Methods}

\subsection{Synthesis of VP1 and VP2 DNA and Construction of Gene Expression Vector}

Fragments containing VP1 (579 bp) or VP2 (528 bp) genes were amplified from the pBHA vector containing a full length of the capsid gene of AcSBV-Kor [21]. Primers used in this work were designed based on the nucleotide sequences of AcSBV-Kor (GenBank accession no. HQ322114): the VP1 gene (forward: 5'-TCGCGGATCCGAATTCGACATTTTGCGT AGACCAGTGTTGT- $3^{\prime}$ and reverse: $5^{\prime}$ - CCGCAAGCTTGTCGACTGGCCCATAAAAGTTA GACAC CTC-3') and the VP2 gene (forward: 5'-TCGCGGATCCGAATTCT GGATGCCTAT AAATTCAATTAAGGTACA-3' and reverse: $5^{\prime}$-CCGCA AGCTTGTCGACGACTTTGTACG 
ACATTCCCGCAAAT-3'). EcoRI and SalI sites (underlined) were engineered into each primer. PCR reaction $(50 \mu \mathrm{L})$ contained $5 \times$ PCR buffer $(10 \mu \mathrm{L}), 10 \mathrm{mM}$ dNTPs $(5 \mu \mathrm{L})$, 10 pmol of each primer, $1 \mathrm{ng}$ plasmid DNA, and $0.4 \mu \mathrm{L}$ (1 U) SuPrime HF DNA Polymerase (GeNet Bio, Daejeon, Korea). The reaction was carried out under the following conditions: 1 cycle of $98^{\circ} \mathrm{C}$ for $2 \mathrm{~min} ; 35$ cycles of $98^{\circ} \mathrm{C}$ for $30 \mathrm{~s}, 58^{\circ} \mathrm{C}$ for $30 \mathrm{~s}$, and $68^{\circ} \mathrm{C}$ for $2 \mathrm{~min}$; and an additional 1 cycle of $68^{\circ} \mathrm{C}$ for $5 \mathrm{~min}$. Each amplified DNA was double-digested with EcoRI/ SalI and ligated into Novagen ${ }^{\circledR}$ pET-28a (+) (MilliporeSigma, Burlington, MS, USA) to yield the recombinant vector. The resultant vectors (pET28a-VP1 and pET28a-VP2) were transformed into E. coli BL21(DE3) and inoculated into Luria-Bertani (LB) agar medium containing kanamycin $(50 \mu \mathrm{g} / \mathrm{mL})$ and grown overnight at $37^{\circ} \mathrm{C}$.

\subsection{Inducible Expression and Purification of Recombinant Protein and SDS-PAGE}

A selected single colony was cultured at $37^{\circ} \mathrm{C}$ in LB liquid medium supplemented with kanamycin $(50 \mu \mathrm{g} / \mathrm{mL})$ until the $\mathrm{OD}_{600 \mathrm{~nm}}$ reached 0.6 and was then induced by adding isopropyl $\beta$-D-1-thiogalactopyranoside (IPTG) at a final concentration of $1.0 \mathrm{mM}$ at $37^{\circ} \mathrm{C}$ for $4 \mathrm{~h}$. Bacterial cells were harvested by centrifugation and further subjected to sonication in lysis buffer ( $10 \mathrm{mM}$ imidazole, $300 \mathrm{mM} \mathrm{NaCl}, 50 \mathrm{mM} \mathrm{NaH} \mathrm{PO}_{4}, \mathrm{pH}$ 8.0). Two recombinant proteins (rVP1 and rVP2) were purified from E. coli cells using a NiNTA resin column under denaturing conditions according to the manufacturer's manual (Qiagen, Hilden, Germany), and recombinant proteins were analyzed by sodium dodecyl sulfate-polyacrylamide gel electrophoresis (SDS-PAGE) as described previously [21].

\subsection{Immunization and Production of Polyclonal Antibody}

All animal procedures were approved by the Ethics Committee of Pai Chai University. The purified rVP1 and rVP2 proteins were dialyzed twice against $1 \times$ phosphate-buffered saline (PBS) for $1.5 \mathrm{~h}$ at $4{ }^{\circ} \mathrm{C}$ and used as immunogens. The polyclonal antiserum was prepared by injecting three BALB/c mice (male, six-week-old) with each recombinant protein. The injection schedule, method, and materials were the same as described previously [21]. Three immunizations were given to mice in 2-week intervals, and each antiserum was recovered from the mouse's blood one week after every injection. The purified rVP1 and rVP2 $(2000,1000,500,250,125$, and $62.5 \mathrm{ng} / 20 \mu \mathrm{L})$ were separated by $10 \%$ SDS-PAGE and tested with each antiserum by Western blot analysis as described below. Furthermore, the immunoglobulin G (IgG) was purified using Montage ${ }^{\mathrm{TM}}$ Antibody Purification Kits with Prosep-G media according to the manufacturer's protocol (MilliporeSigma) and adjusted to $1 \mathrm{mg} / \mathrm{mL}$ concentration.

\subsection{ELISA, SDS-PAGE, and Western Blot Analysis}

To test IgG purified from each antiserum (6-week collection), an aliquot (50 $\mu \mathrm{L})$ of antigen $(31.25,62.5,125,250$, and $500 \mathrm{ng} / \mathrm{mL}$ of rVP1 and rVP2 in coating buffer) was added to a microtiter plate. The plate was blocked with PBS-T (PBS containing $0.05 \%$ Tween-20) containing 1\% bovine serum albumin (BSA)at room temperature for $2 \mathrm{~h}$. After washing the plate with PBS-T, pAb-rVP1 and pAb-rVP2 (1:1000, $v / v$ in blocking buffer) were added and incubated at room temperature for $2 \mathrm{~h}$. After adding alkaline phosphataseconjugated goat anti-mouse $\operatorname{IgG}(1: 5000, v / v$ in blocking buffer, MilliporeSigma), the plate was incubated at room temperature for $2 \mathrm{~h}$. After washing with PBS-T, p-nitrophenyl phosphate (MilliporeSigma) was added and further incubated at room temperature for $2 \mathrm{~h}$. The absorbance at $450 \mathrm{~nm}$ was measured using a microplate reader (Bio-Rad, Hercules, CA, USA). A sample was considered positive if the mean absorbance value of the six replicates was more than double that of the PBS buffer control. SDS-PAGE gels $(10 \%)$ separated the purified rVP1 and rVP2 proteins, as well as crude protein extracts from healthy honeybees, AvSBV-infected honeybees, and larvae (Samcheok, Gangwon-do, Korea). The unstained gel was blotted onto a polyvinylidene fluoride (PVDF) membrane (MilliporeSigma) using wet electro-transfer apparatus (Bio-Rad). The membrane was blocked with skim milk (5\%) in Tris-buffered saline (TBS; $137 \mathrm{mM}$ sodium chloride, $20 \mathrm{mM}$ Tris, $\mathrm{pH} 7.4$ ) for $1 \mathrm{~h}$ at 
$37^{\circ} \mathrm{C}$. The membrane was washed thrice in TBS-T (0.1\% Tween-20 in TBS) and incubated at $4{ }^{\circ} \mathrm{C}$ overnight with a primary antibody (1:1000 dilution of pAb-rVP1 and pAb-rVP2, $v / v)$. After washing thrice with TBS-T, the membrane was incubated at $37^{\circ} \mathrm{C}$ for $1 \mathrm{~h}$ with a secondary antibody (1:10,000 dilution of alkaline phosphatase-conjugated goat anti-mouse antibody, $v / v)$. Then, nitro blue tetrazolium $(100 \mu \mathrm{L})$ was added to alkaline phosphatase buffer $(15 \mathrm{~mL})$ before mixing with 5-bromo-4-chloro-3-indolylphosphate $(50 \mu \mathrm{L})$ to stain the membrane.

\subsection{Preparation of Splenocyte and Hybridoma Production and Selection}

Hybridomas were generated using the ClonaCell-HY Hybridoma Cloning Kit according to the manufacturer's instructions (Stemcell Technologies Inc., Vancouver, BC, Canada). The spleen was disaggregated into a single-cell suspension in Medium B and the cell suspension was centrifuged at $300 \times g$ for $10 \mathrm{~min}$ at room temperature (a total of 3 cycles). After resuspension of the cells in Medium B $(25 \mathrm{~mL})$, and the volume of cell suspension was calculated $\left(1 \times 10^{8}\right.$ cells). The myeloma cells (SP2/0-Ag14, CRL-1581) in Medium A were incubated for 4 days $\left(37^{\circ} \mathrm{C}, 5 \% \mathrm{CO}_{2}\right)$, and the cell suspension was centrifuged at $300 \times g$ for $10 \mathrm{~min}$. After adding additional Medium B to the supernatants, the cell suspension was centrifuged at $300 \times g$ for $10 \mathrm{~min}$ (a total of 3 cycles). After resuspension of the cells in Medium B $(25 \mathrm{~mL})$, the volume of cell suspension was calculated $\left(2 \times 10^{7}\right.$ cells $)$. Myeloma cells were fused with spleen cells using ClonaCell ${ }^{\mathrm{TM}}-\mathrm{HY}$ PEG $(0.5 \mathrm{~mL})$, and Medium B $(5 \mathrm{~mL})$ was added to the fusion mixture. After dropwise adding Medium $\mathrm{C}(5 \mathrm{~mL})$, the mixture was incubated for $24 \mathrm{~h}\left(37^{\circ} \mathrm{C}, 5 \% \mathrm{CO}_{2}\right)$. The fused cell suspension was mixed with Medium D vigorously, transferred into a $50 \mathrm{~mL}$ conical tube, and centrifuged at $400 \times g$ for $10 \mathrm{~min}$. The cells were resuspended in Medium $\mathrm{C}$ (made up to $3 \mathrm{~mL}$ ), transferred into a bottle containing Medium D (10 mL), gently inverted several times, and incubated at room temperature for $15 \mathrm{~min}$. The cell suspension in Medium D $(9.5 \mathrm{~mL})$ was slowly added to Petri dishes using a $12 \mathrm{~mL}$ syringe with a 16-gauge blunt-end needle and incubated for 10-14 days. Each clone was pipetted into an individual well of a 96-well tissue culture plate containing Medium E $(200 \mu \mathrm{L})$, and the plates were incubated for 4 days. To achieve monoclonality, hybridoma cell suspension (100 cells $/ 1 \mathrm{~mL}$ ) was mixed with Medium D $(9 \mathrm{~mL})$. The mixture was plated in a Petri dish and incubated for 14 days. Twenty-four clones were incubated in 96-well microplates containing Medium E (200 $\mu \mathrm{L} /$ well), and supernatants from the microplates were screened by Western blotting using the purified rVP1 and rVP2.

\subsection{Generation of Ascities Fluids}

After screening by Western blotting, the positive hybridoma cells $\left(4 \times 10^{6}\right)$ were suspended in Medium $\mathrm{E}$ and injected into the peritoneal cavity of a Freund's incomplete adjuvant $(0.5 \mathrm{~mL})$-primed mouse using a 26-gauge needle. After 10 days, the mouse developed a large quantity of ascites fluid, and the abdominal cavity was opened by cutting after sacrificing the mouse. Ascites fluid was drawn using a $10 \mathrm{~mL}$ syringe fitted with an 18-gauge needle, aseptically collected from anesthetized mice by abdominal paracentesis using an 18-gauge needle, and then transferred into sterile centrifuge tubes. The fluid was centrifuged at $200 \times g$ for $10 \mathrm{~min}$ at $4{ }^{\circ} \mathrm{C}$. The supernatant fluid was collected and frozen at $-70{ }^{\circ} \mathrm{C}$ until further use.

\subsection{Purification of $m A b s, S D S-P A G E$, and Western Blot Analysis}

Immunoglobulin G (IgG) was purified using a Proteus Antibody Purification Kit Protein A (Bio-Rad) according to the manufacturer's protocol (MilliporeSigma). The concentrations of mAb-rVP1 and mAb-rVP2 were adjusted to $1 \mathrm{mg} / \mathrm{mL}$, mixed with glycerol $(50 \%, v / v)$, and stored at $-20{ }^{\circ} \mathrm{C}$ until use. Crude protein extracts from the healthy honeybee, AvSBV-infected honeybee, and larva samples were included. Diluted mAb-rVP1 and mAb-rVP2 $(1: 1000, v / v)$ were used as primary antibodies, and diluted goat anti-mouse phosphatase conjugate $(1: 10,000, v / v$, MilliporeSigma) was used as a secondary antibody. 


\subsection{Preparation of Colloidal Gold and Colloidal Gold-pAb Conjugate}

Firstly, $0.01 \% \mathrm{HAuCl}_{4}$ in double-distilled water was boiled with rapid stirring, and $1 \%$ trisodium citrate $(2 \mathrm{~mL})$ was added to the solution. The colloidal gold solution was boiled for an additional $10 \mathrm{~min}$ and continuously stirred until it had cooled. Secondly, the colloidal gold solution was adjusted to $\mathrm{pH} 8.2$ using $1 \%$ potassium carbonate. Thirdly, each $\mathrm{pAb}(300 \mu \mathrm{L}$ of $1 \mathrm{mg} / \mathrm{mL})$ was mixed with $20 \mathrm{~mL}$ of a colloidal gold solution by vigorous stirring for $30 \mathrm{~min}$. The mixture was added to $2.5 \mathrm{~mL}$ of $10 \%$ bovine serum albumin and stirred for an additional $30 \mathrm{~min}$. The mixture was centrifuged at $6000 \times g$ for $45 \mathrm{~min}$ at $4{ }^{\circ} \mathrm{C}$, then the resulting conjugate pellet was resuspended and washed twice with $2 \mathrm{mM}$ borax buffer (pH 9.0) containing 0.1\% PEG 20000, followed by resuspension in $1 \mathrm{~mL}$ of the same buffer.

\subsection{Preparation of IC Strip Device and Procedure for the Test}

The sample pads (Millipore cellulose fiber: MilliporeSigma) and the conjugate pads (Millipore glass-fiber membrane: MilliporeSigma) were treated with $20 \mathrm{mM}$ phosphate buffer containing $2 \%$ BSA, $2.5 \%$ sucrose, $1 \%$ Tween $20,0.3 \%$ polyvinylpyrrolidone K30, and $0.02 \%$ sodium azide ( $\mathrm{pH} 7.4$ ) and dried for $1 \mathrm{~h}$ at $37^{\circ} \mathrm{C}$. The $\mathrm{mAb}-\mathrm{rVP} 1, \mathrm{mAb}-\mathrm{rVP} 2$ $(1 \mathrm{mg} / \mathrm{mL})$, and the goat anti-mouse antibody $(1 \mathrm{mg} / \mathrm{mL})$ in $1 \times$ PBS were dispensed at the test line and the control line on the Millipore nitrocellulose membrane. The pAb-rVP1 and pAb-rVP2 colloidal gold conjugates were applied to the treated conjugate pad at a rate of $10 \mu \mathrm{L} / \mathrm{cm}$ (about $1.5 \mathrm{~g} / \mathrm{cm}$ ) and then completely lyophilized. The absorption pad, nitrocellulose membrane, pretreated conjugate pad, and sample pad were assembled as a test strip and attached to a plastic scale board. A complete set for the IC strip was manufactured by GeNet Bio Co (Daejeon, Korea). Samples were prepared from larvae $(0.3 \sim 0.5 \mathrm{~cm})$ in Eppendorf tubes containing $1 \times$ PBS using a disposable plastic homogenizer. The resulting extract was centrifuged at $8000 \mathrm{rpm}$ for $30 \mathrm{~s}$, and the supernatant was used as a liquid sample. During the assay, a single drop ( $50 \mu \mathrm{L} /$ drop) of the liquid sample and two drops of diluent buffer $(1 \times$ PBS) were added to the sample pad, and it rapidly diffused into the conjugate pad. If a sample contains the target antigens (VP1 and VP2), it reacts with the colloidal gold-conjugated pAb-rVP1 and pAb-rVP2 to form an antigen colloidal gold-pAb complex. The complex migrates along the nitrocellulose membrane chromatographically and reacts with immobilized mAb-rVP1 and mAb-rVP2 on the test line to form a colored band. The excess conjugate, or free conjugate if the sample does not contain the target antigen, migrates along the membrane to the control line, where it interacts with immobilized goat anti-mouse antibody to form a colored band. Therefore, two bands will be displayed for a positive sample, one at the test line and one at the control line, while a negative sample will show only one band at the control line within 10 min.

\subsection{Real-Time RT-PCR}

Total RNA was isolated from larvae using RNAiso Plus according to the manufacturer's instructions (Takara Bio, Shiga, Japan). The RT reaction was performed in a reaction mixture $(20 \mu \mathrm{L})$ containing $1 \mu \mathrm{L}$ of total RNA (100 ng), $10 \mu \mathrm{L}$ of $2 \times$ SuPrimeScript RT premix, and $1 \mu \mathrm{L}$ of 20 pmol of reverse primer (GeNet Bio, Daejeon, Korea). The thermal cycler was programmed for $1 \mathrm{RT}$ cycle at $50^{\circ} \mathrm{C}$ for $60 \mathrm{~min}$ and $70{ }^{\circ} \mathrm{C}$ for $10 \mathrm{~min}$. PCR amplification was performed in 96-well plates by using an Applied Biosystem 7500 Real-Time PCR Instrument System. The reaction mixture $(20 \mu \mathrm{L})$ contained $5 \mu \mathrm{L}$ of template DNAs, $10 \mu \mathrm{L}$ of $2 \times$ SYBR Green I-based Prime Q-Master Mix (GeNet Bio, Daejeon, Korea), $5 \mu \mathrm{L}$ of $4 \times$ oligo mixture, and primer pairs at 10 pmol. A primer set was designed to cover a part of the VP1 gene (forward: 5'-CATGGAGAGACAAA GGCGATAC- $3^{\prime}$ and reverse: $5^{\prime}$-GCTTCTACCCACACAGACATATT-3') and the VP2 gene (forward: $5^{\prime}$-TGCGCGCCCA ATACTATAC- $3^{\prime}$ and reverse: $5^{\prime}-$ CTTTCCCGCACTGAAACTTATTAC- $\left.3^{\prime}\right)$. The reaction was performed under the following conditions: one cycle of initial denaturation at $95{ }^{\circ} \mathrm{C}$ for $10 \mathrm{~min}, 40$ cycles of denaturation at $95^{\circ} \mathrm{C}$ for $10 \mathrm{~s}$, and annealing extension at $60^{\circ} \mathrm{C}$ for $30 \mathrm{~s}$. The experiments were analyzed with auto-baseline and manual thresholds chosen from 
the exponential phase of the PCR amplification. After the data analysis, the cycle threshold $(\mathrm{Ct})$ number and DeltaRn $(\mathrm{dRn})$ were used for statistical analyses. Data were analyzed using the Applied Biosystems ${ }^{\mathrm{TM}}$ High Resolution Melting (HRM) Software.

For the standard of DNA copy number, we used pET28a-VP1 containing a $579 \mathrm{bp}$ insert and pET28a-VP2 containing a 528 bp insert. A ten-fold serial dilution series of the pET28a-VP1 and pET28a-VP2 ranging from $1 \times 10^{3}$ to $1 \times 10^{6}$ copies $/ \mu \mathrm{L}$, was used to construct the standard curves for both VP1 andVP2. The concentration of the plasmid was measured using a fluorometer and the corresponding copy number was calculated using the following equation: DNA (copy) $=6.02 \times 10^{23}$ (copy/mol) $\times$ DNA amount $(\mathrm{g}) / \mathrm{DNA}$ length $(\mathrm{bp}) \times 660(\mathrm{~g} / \mathrm{mol} / \mathrm{bp})$ [48]. The plot of a standard curve of Ct values against the logarithmic dilutions produced a regression line $\left(y=-3.8356 x+42.7930, R^{2}=0.9965\right)$ for the VP1 and a regression line $\left(y=-3.7314 x+43.5159, R^{2}=0.9933\right)$ for the VP2. The data was shown as Figure S4 in Supplementary Materials.

\subsection{Detection Limit (Sensitivity) of the IC strips and Validation (Specificity) of the IC Strips Using Field Samples}

A total of 100 larva samples were collected from two beekeeping farms in the Sejong (Chungcheongnam-do) and Samcheok (Gangwon-do) areas of Korea and tested by realtime PCR for the presence of AcSBV. The limit of antibody pairs (pAb-rVP1/mAb-VP1-1 and pAb-rVP2/mAb-VP2-13) embedded in a membrane-based strip in detecting AcSBV was determined by using serial dilutions of real-time PCR positive reference samples $\left(3.02 \times 10^{6}, 4.33 \times 10^{5}, 1.38 \times 10^{4}, 1.38 \times 10^{3}\right.$ copies). In addition, real-time PCR-positive (50 infected) and -negative (50 healthy) samples were tested with IC strips for the validation of AcSBV diagnosis. Each diluted sample was tested in triplicate using different IC strips.

\section{Results}

\subsection{Expression and Purification of the Recombinant Protein VP1 (rVP1) and VP2 (rVP2)}

VP1 and VP2 are located at the C-terminus and N-terminus of AcSBV capsid protein (Figure 1A). Both rVP1 and rVP2 were expressed as inclusion bodies (Figure 1B), suggesting that these recombinant proteins were not soluble in E. coli. Prominent bands at the expected molecular weights of $26.73 \mathrm{kDa}$ (for rVP1) and $24.86 \mathrm{kDa}$ (for rVP2) were observed in the insoluble fraction of the bacterial lysate containing the pET-28a-VP1 and pET-28a-VP2 vectors, respectively, while no protein band of similar size was observed in the insoluble fraction of the wild-type lysate (Figure 1C). To purify rVP1 and rVP2, we treated urea to denature the inclusion bodies and performed purification using the Ni-NTA column system. Each recombinant protein was purified effectively after two cycles of washing/elution (Figure 1D).

\subsection{Reactivity Test of Antiserum by Western Blot and ELISA}

Mice injected with the purified rVP1 and rVP2 effectively produced polyclonal antisera pAb-rVP1 and pAb-rVP2, respectively. To determine the reactivity of raised antisera, each antiserum was tested with a serial dilution of rVP1 and rVP2. In Western blot analysis, pAb-rVP1 could detect its antigen $(26.73 \mathrm{kDa})$ at a concentration as low as $500 \mathrm{ng}$ (Figure $2 \mathrm{~A}$, lane 3$)$, and pAb-rVP2 could detect its antigen $(24.86 \mathrm{kDa})$ at a loading of as low as $62.5 \mathrm{ng}$ under given experimental conditions (Figure 2B, lane 6). No corresponding protein band was observed when a pre-immune antiserum was used in Western blot analysis (data not shown). To improve the sensitivity of pAb-rVP1 and pAb-rVP2, each polyclonal antiserum, including control mouse serum, was further purified to IgG using a commercial kit. Each IgG was visualized using Coomassie brilliant blue-stained SDS-PAGE gels and used as a primary antibody for Western blot analysis. As expected, pAb-rVP1 and pAb-rVP2 distinctly reacted with respective antigens (Figure S1). To quantitatively measure the reactivity, pAb-rVP1 and pAb-rVP2 were subjected to ELISA using the purified rVP1 and rVP2, respectively. Each pAb reacted positively in ELISA against a series of rVP1 and rVP2 concentrations (500, 250, 125, 62.5, and $31.3 \mathrm{ng} / \mathrm{mL}$ ). ELISA values of 
the rVP1 dilution were $0.358,0.230,0.163$, and 0.114 , yielding a regression line (equation: $y=0.0654 x-0.0055$ ) with a correlation coefficient of 0.957 (Figure 2C). ELISA values of the rVP2 dilution were $0.303,0.229,0.149,0.106$, and 0.075 , yielding a regression line (equation: $y=0.0574 x-0.0007)$ with a correlation coefficient of 0.981 (Figure 2D).

\begin{tabular}{|c|c|c|c|c|c|c|c|c|c|}
\hline \multirow{2}{*}{\multicolumn{2}{|c|}{ A) }} & \multicolumn{4}{|c|}{ capsid protein } & \multicolumn{3}{|c|}{ Non-structural protein } & \multirow[b]{2}{*}{ poly A tail } \\
\hline & & VP2 & VP4 & VP3 & VP1 & Helicase & Protease & RdRp & \\
\hline
\end{tabular}
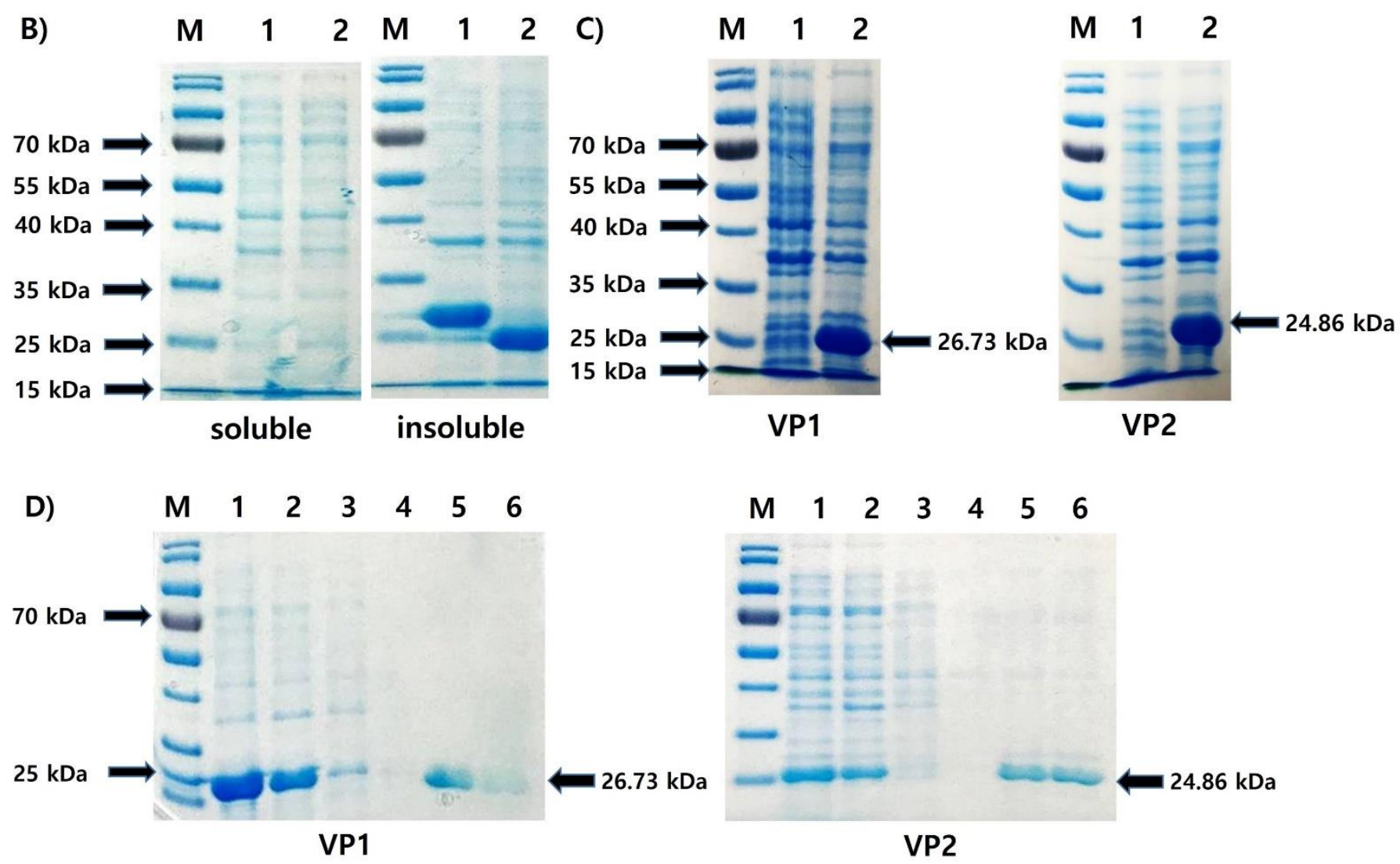

Figure 1. (A) Genome organization of AcSBV. (B) IPTG (final concentration at $1 \mathrm{mM}$ ) induction for the expression of pET-28a vector containing AcSBV-VP1 (lane 1) and AcSBV-VP2 (lane 2). Soluble fraction (left) and insoluble fraction (right) of the Escherichia coli BL21(DE3) transformants. (C) Insoluble fraction of wild-type (lane 1) and transformant (lane 2) E. coli BL21(DE3). (D) Purification of the recombinant VP1 (rVP1) and VP2 (rVP2) proteins by Ni-NTA resin chromatography under denaturing conditions. M: protein molecular weight marker; lanes 1-2: cell lysate 1 and 2; lanes 3-4: first washing and second washing; and lanes 5-6: first elution and second elution. Arrows indicate rVP1 (26.73 kDa) or rVP2 (24.86 kDa).

\subsection{The Specificity and Efficiency of Polyclonal Antibodies}

To test the specificity, pAb-rVP1 and pAb-rVP2 were evaluated with respective homologous and heterologous antigens (rVP1 and rVP2) in the Western blot assay (Figure 3A). After 5 min staining of the membrane with NBT/BCIP, pAb-rVP1 showed clear detection of its homologous antigen rVP1, while pAb-VP2 detected not only the homologous antigen rVP2 but also the heterologous rVP1. After extensive staining (60 min) of the membrane with NBT/BCIP, we found that both pAbs showed a positive reaction with the homologous and heterologous antigens. However, the bands observed for homologous virus antigen-antibody combinations were much stronger than those of heterologous combinations, although each antibody reacted with heterologous antigens in the Western blot. To test the efficiency, pAb-rVP1 and pAb-rVP2 were evaluated with a crude extract from field 
samples (Figure 3B). Both pAbs showed the corresponding native protein present in the crude extract from AcSBV-infected honeybees (lane 3) and larvae (lane 4) but not in the crude extract from healthy honeybees (lane 2).

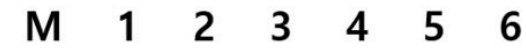

A)
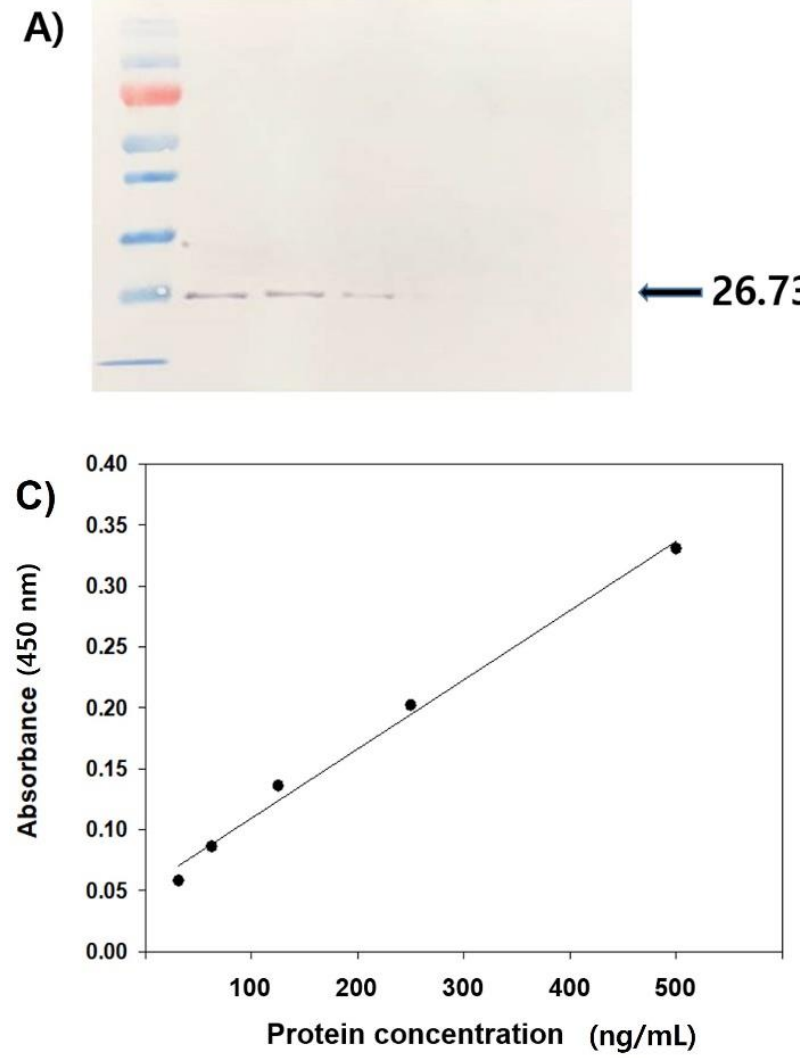

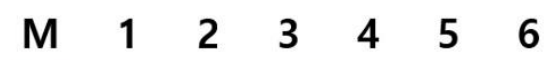

B)

$26.73 \mathrm{kDa}$
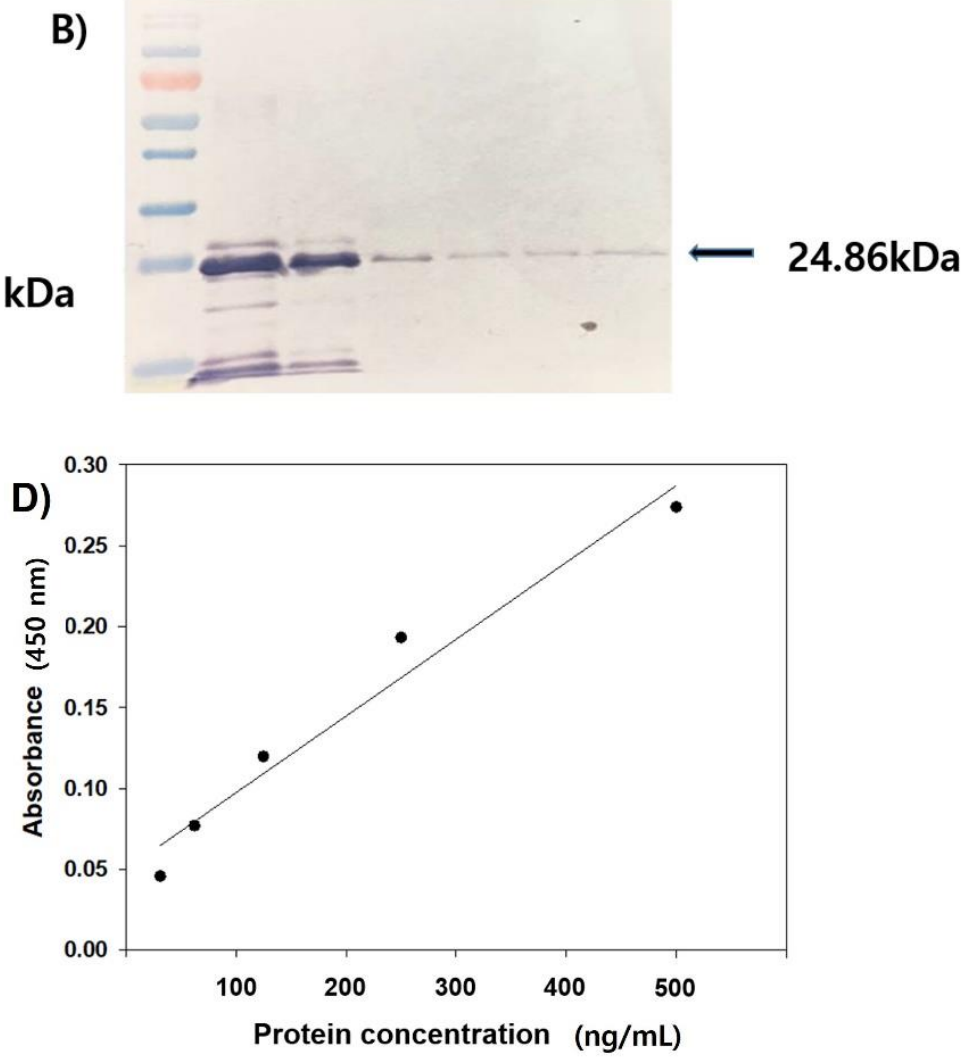

Figure 2. Western blot analysis of the rVP1 (A) and rVP2 (B) using respective polyclonal antisera (pAb-rVP1 and pAb-rVP2) collected at the sixth week. Lanes 1-5 represent the different concentration (2000, 1000, 500, 250, 125, and 62.5 ng) of each protein. Detection by ELISA of serial dilutions (500, 250, 125, 62.5, and $31.3 \mathrm{ng} / \mathrm{mL})$ of the rVP1 (C), and rVP2 (D) using the purified IgG (pAb-rVP1 and pAb-rVP2). ELISA values of the rVP1 dilution yielded a regression line (equation: $y=0.0654 x-0.0055, r=0.957$ ), and the $r V P 2$ dilution yielded a regression line (equation: $y=0.0574 x-0.0007, r=0.981$ ).

\subsection{Selection of $r V P 1$ - and $r$ PP2-Specific $m A$ bs and Their Reactivity to Recombinant Protein and} Honeybee Samples

Based on primary screening by Western blot analysis, ten anti-VP1 mAbs in the supernatant of twenty-four clones and ten anti-VP2 mAbs in the supernatant of twentyfour clones were identified as positive clones. Ascites fluids were collected from ascites tumor-forming mice (Figure S2) and further purified to IgG using Proteus Antibody Purification Kit Protein A (Figure S3). Ultimately, positive hybridoma cells secreting mAb-rVP1 and $\mathrm{mAb}-\mathrm{rVP} 2$ were selected (Figure 4A). Each of these was designated as mAb-rVP1-1 and $\mathrm{mAb}-\mathrm{rVP} 2-13$ and showed a strongly positive band in Western blot analysis. As expected, $\mathrm{mAb}$-VP1-1 and mAb-VP2-13 bound to only homologous rVP1 (26.7 kDa) and rVP2 $(24.9 \mathrm{kDa})$, respectively, without heterologous antigen binding (Figure 4B). To confirm their specificities, field samples were subject to Western blot analysis using mAb-rVP1-1 and mAb-rVP2-13 (Figure 4C). Each mAb reacted with infected honeybees and larvae as well as the corresponding respective recombinant proteins. Two specific $m A b s$ showed a stronger reaction to AcSBV in larvae than honeybees because the larval stage is the most susceptible to SBV infection. However, they did not react with healthy honeybees (Figure 4C, lane 2). Therefore, each $\mathrm{mAb}$ was used for further experiments. 


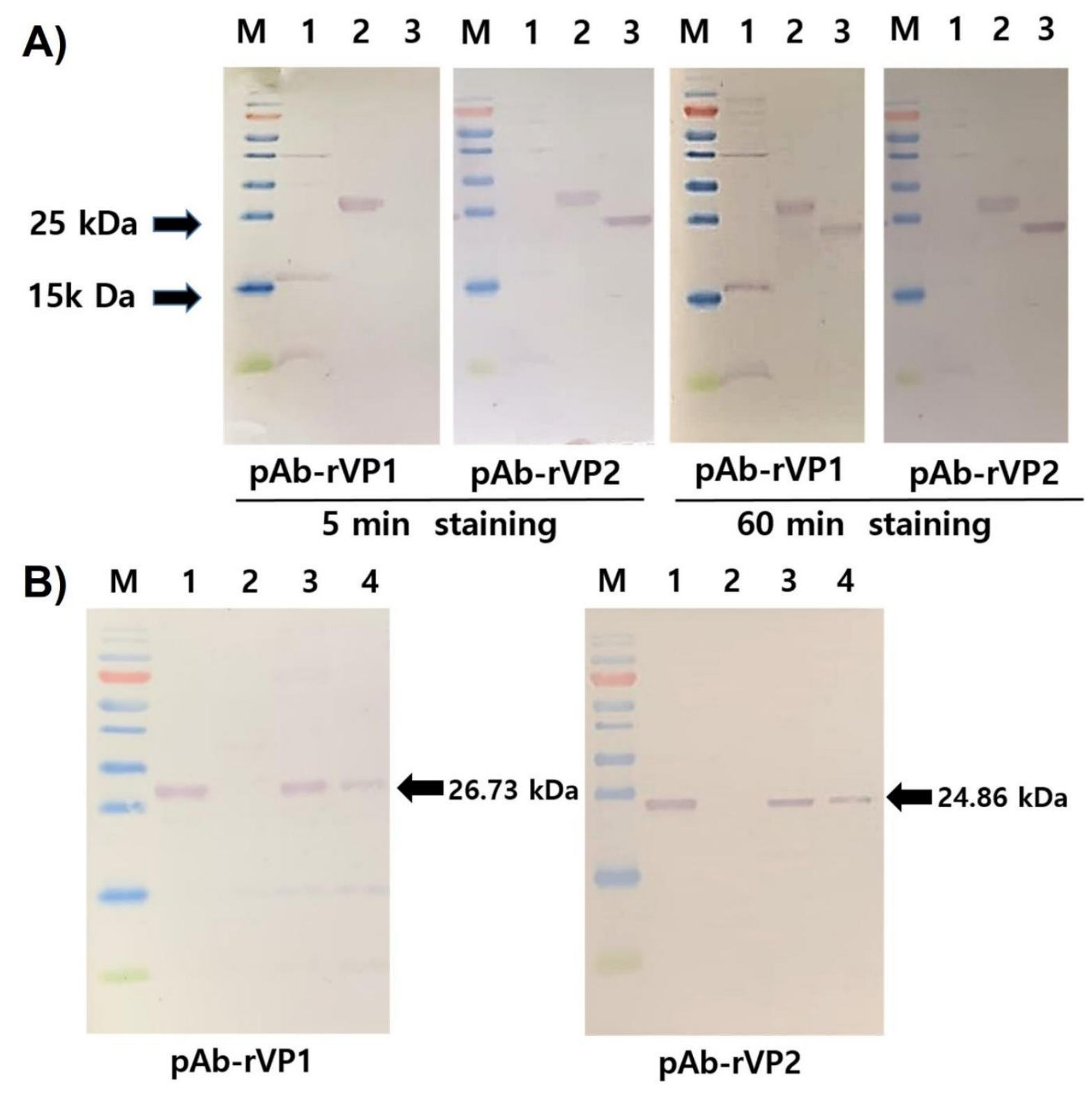

Figure 3. (A) Western blot analysis of rVP1 and rVP2 (lanes 1-3, $5 \mu$ g each) using pAb-rVP1 and pAb-rVP2 and (B) Western blot analysis of rVP1, rVP2 (lane 1, $5 \mu \mathrm{g}$ each), crude protein extract from healthy honeybees (lane 2, $20 \mu \mathrm{g}$ ), crude protein extract from AcSBV-infected honeybees (lane 3, $20 \mu \mathrm{g}$ ), and AcSBV-infected larvae (lane 4, $20 \mu \mathrm{g}$ ) using pAb-rVP1 (left) and pAb-rVP2 (right).

3.5. Antigen Detection Limit (Sensitivity) of the IC Strips Using $p A b$ as a Detector Antibody and $m A b$ as a Capture Antibody

The IC assay was designed in the form of a sandwich, using two specific antibodies, mAb-rVP1-1 and mAb-rVP2-13, immobilized on a nitrocellulose membrane at separated test lines, while other specific antibodies, pAb-rVP1 and pAb-rVP2, were conjugated with gold nanoparticles. The gold-bound conjugated pAb-rVP1 and pAb-rVP2 can be bound by a target antigen present in the sample instead of the mAb-rVP1-1 and mAbrVP2-13 embedded at the test lines. No reaction was observed with the negative control of the IC assay developed in this study (Figure 5). The antibody pair, pAb-rVP1/mAbVP1-1, showed positive reactivity as low as $1.38 \times 10^{3}$ copies, while the other pair, pAb$\mathrm{rVP} 2 / \mathrm{mAb}-\mathrm{VP} 2-13$, showed positive reactivity as low as $1.38 \times 10^{4}$ copies. Therefore, $\mathrm{pAb}-\mathrm{rVP} 1 / \mathrm{mAb}-\mathrm{VP} 1-1$ was selected as a final candidate for the validation. 
Hybridoma-mAb-rVP1-1

A)

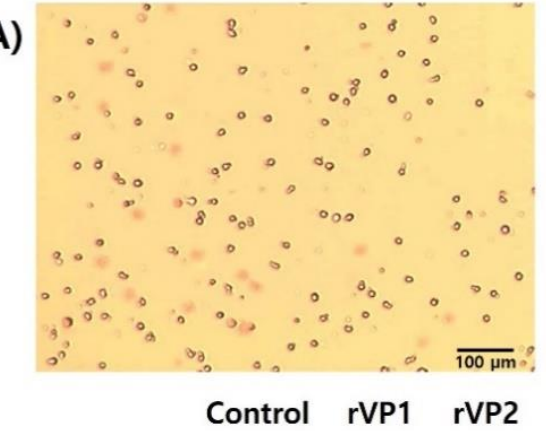

B)

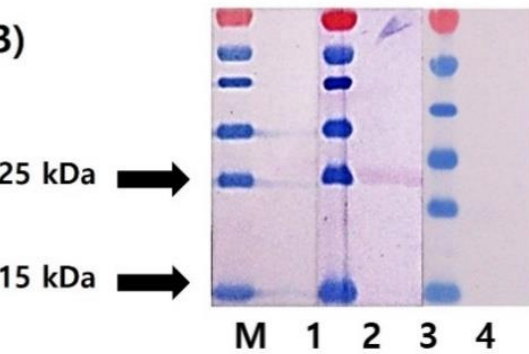

C)

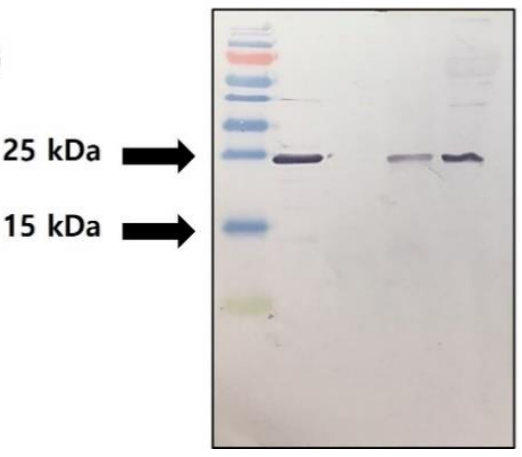

Hybridoma-mAb-rVP2-13
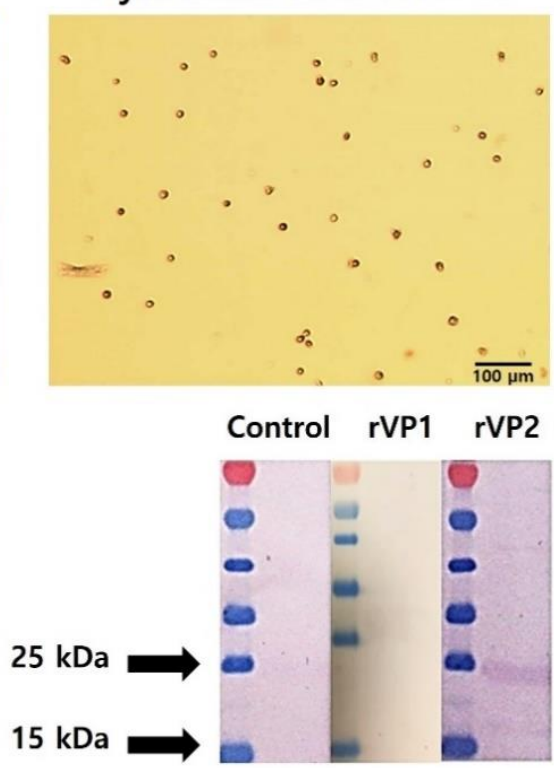

$5 \mathrm{kDa}$
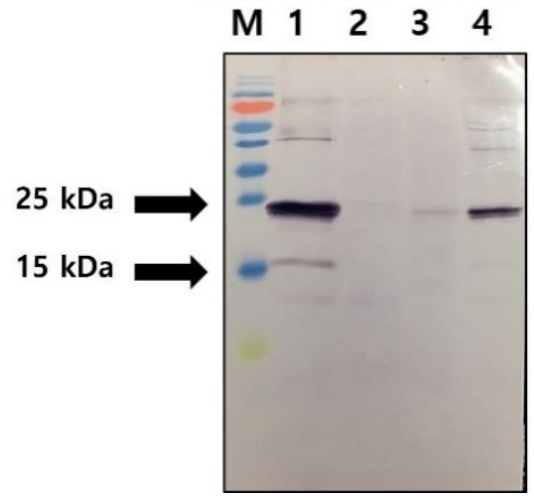

Figure 4. (A) Hybridoma clones with the highest titer of anti-rVP1 (left) and anti-rVP2 (right); (B) screening by Western blot analysis showed that mAb-VP1-1 and mAb-VP2-13 reacted strongly against rVP1 and rVP2, respectively; and (C) immunoreactivity of mAb-VP1-1 and mAb-VP2-13 with field samples in Western blotting. Lane 1: the purified recombinant protein (rVP1, rVP2); lane 2: healthy honeybees, lane 3: infected honeybees; and lane 4: infected larvae.

\subsection{Validation (Specificity) of the IC Strips Using $p A b$ as a Detector Antibody and $m A b$ as a Capture Antibody}

Fifty field samples (various copy numbers from $9.83 \times 10^{2}$ to $1.22 \times 10^{6}$ ) identified positively by real-time PCR showed a positive reaction in the IC strips coated with antibody pair pAb-rVP1/mAb-VP1-1 (Table 1, Figure S5). On the other hand, 50 samples identified as negative by real-time RT-PCR showed a negative reaction in the IC strips coated with antibody pair pAb-rVP1/mAb-VP1-1 (Table 1, Figure S6). The antibody pair demonstrated high sensitivity and specificity and did not cross-react with the non-infected samples at all. The specificity of mAb-VP1-1 was similar to that of real-time PCR; a different quantity of virus infection was shown. The high agreement between the IC and real-time PCR assays suggests that the IC assay is a very useful method for the rapid and accurate diagnosis of honeybees and larvae infected with AcSBV. A further test with more samples collected nationwide needs to be commercialized as a diagnostic kit for the rapid, sensitive, and specific detection of AcSBV. 


\section{Real-time RT-PCR}
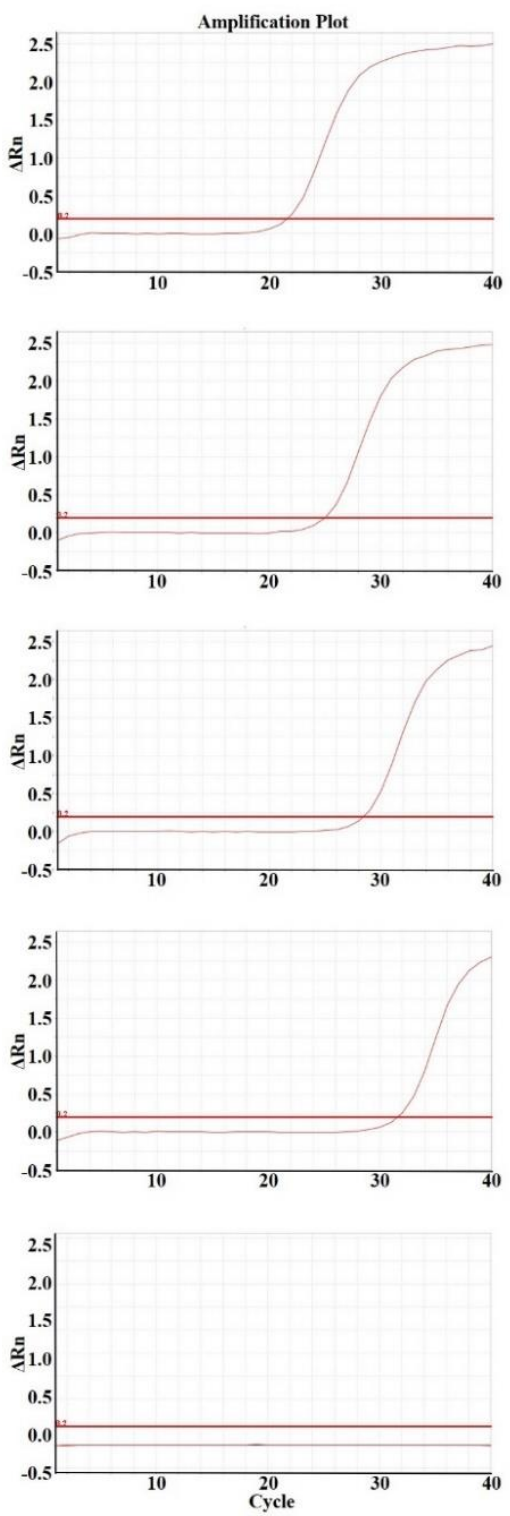

\section{$3.02 \times 10^{6}$ copies}

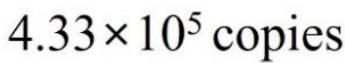

$1.38 \times 10^{4}$ copies

\section{$1.38 \times 10^{3}$ copies}

Non-infected
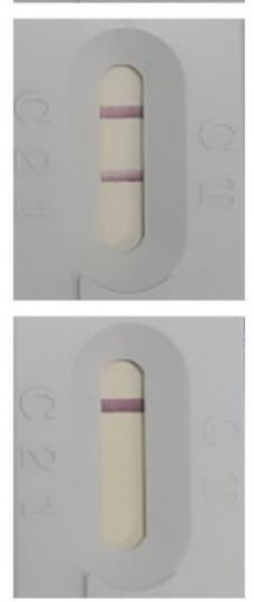

mAb-VP2-13
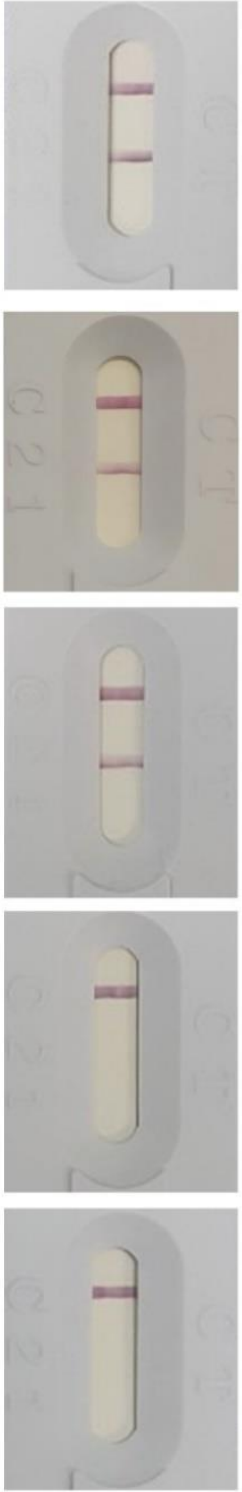

Figure 5. Detection limit of the IC assay with gold-conjugated VP1-specific and VP2-specific mAbs. The reference sample was serially diluted (10-fold) from $10^{3}$ to $10^{6}$ copies. Each diluted sample was amplified by real-time RT-qPCR and compared to standard curves in Figure S4.

Table 1. Comparative evaluation of AcSBV-infected larva samples by real-time PCR and IC strips coated with pAb-rVP1 as a detector antibody and mAb-VP1-1 as a capture antibody.

\begin{tabular}{cccc}
\hline \multirow{2}{*}{ Real-Time RT-PCR } & \multicolumn{2}{c}{ Rapid Strip Test } \\
\cline { 2 - 4 } & Positive & Negative & Total \\
\hline Positive & 50 & 0 & 50 \\
Negative & 0 & 50 & 50 \\
Total & 50 & 50 & 100 \\
\hline
\end{tabular}

${ }^{1}$ copy number: $9.83 \times 10^{2} \sim 1.22 \times 10^{6}$.

\section{Discussion}

SDS-PAGE, Western blot, and ELISA results confirmed that the AcSBV-rVP1 and AcSBV-rVP2 were successfully expressed in E. coli. Previously, three structural protein genes (VP1,VP2, and VP3) of CSBV (GenBank accession no. HM237361.1) were successfully 
expressed in the pGEX-6P-1 bacterial expression system using codon optimization, and each recombinant protein was used for the production of polyclonal antiserum [49]. Based on the sequence alignment, the VP1 and VP2 proteins of AcSBV-Kor share $96.4 \%$ and $96.6 \%$ amino acid identity with those of CSBV. This suggests that the polyclonal antiserum directed against the recombinant proteins (structural proteins) of AcSBV-Kor can cross-react with their structural protein counterparts in CSBV.

AcSBV-VP2 comprises the N-terminal end (residue 213) to residue 388 of the coat protein, while AcSBV-VP1 comprises residues from 774 to the C-terminal end (residue 965) of the coat protein. AcSBV-VP2 shares $38.4 \%$ nucleotide and $69.8 \%$ amino acid identity with AcSBV-VP1 based on the sequence alignment. In this study, rVP1 and rVP2 were evaluated for their antigenicity against their specific antibody and each other. In Western blot analysis, pAb-rV1 showed a strong specificity to the homologous antigen and a weak specificity to the heterologous antigen. pAb-rVP2 reacted strongly with both homologous and heterologous antigens. This suggests that pAb-rVP1 is less sensitive but has a higher specificity than pAb-rVP2. Our results also indicate that rVP2 shares major immunerelevant domains with $\mathrm{rVP} 1$ and that both recombinant proteins present authentic viral epitopes. On the other hand, mAb-VP1-1 and mAb-VP2-13 were bound only to their homologous antigens. Both pAbs (pAb-rVP1 and pAb-rVP2) and mAbs (mAb-rVP1 and $\mathrm{mAb}-\mathrm{rVP} 2$ ) are able to recognize native virus particles in field samples, providing the required basis for the development of the IC kit.

A critical factor of IC assay design is optimal selection of an antibody that shows sensitive and specific detection of a target antigen. Ultimately, the performance of the IC assay relies on the antibody affinity when binding an antigen in a sample. In a typical sandwich format, either a single $\mathrm{mAb}$ or two different $\mathrm{mAbs}$ are used as a detector antibody and a capture antibody in the IC strips [32]. In the case of low sample loading, the use of the same $\mathrm{mAb}$ for detection and capture in the IC assay showed poor detection sensitivity because of competition for the same epitope between the detector and capture mAbs [50]. The use of two different mAbs in the IC assay is an expensive suggestion, limiting its practical usefulness in POCT. Furthermore, the detector $\mathrm{mAb}$ binding to an epitope has the possibility of affecting other spatially unrelated epitopes in a way that could modify binding to the capture $\mathrm{mAb}$ [51].

Alternatively, $\mathrm{mAb}$ has been applied as a detector antibody, while $\mathrm{pAb}$ was applied as a capture antibody [32], and vice versa [41]. Utilizing $\mathrm{mAb}$ as a detector antibody and $\mathrm{pAb}$ as a capture antibody may result in alteration of some of the original epitopes, leaving the rest of the epitopes unaltered and accessible to the polyclonal capture antibodies [32]. Furthermore, pAbs are generally less expensive and faster to produce than mAbs. Hence, the present strip test based on a combination of $\mathrm{mAb}$ and $\mathrm{pAb}$ provides an acceptable alternative for onsite and cost-effective diagnosis of AcSBV infection.

Antibody pairs that can simultaneously bind to the target antigen with high sensitivity and specificity are required for a sandwich assay. In this study, we developed an IC test strip for detecting AcSBV using two pairs of antibodies (pAb-rVP1/mAb-rVP1-1 and $\mathrm{pAb}-\mathrm{rVP} 2 / \mathrm{mAb}-\mathrm{rVP} 2-13)$. This design helps to accumulate the target antigen on the pAb-rVP1- or pAb-rVP2-conjugated pad, therefore enhancing the detection of antigenantibody binding to increase the sensitivity. As shown in Figure 5, the antibody pair of pAb-rVP1/mAb-rVP1-1 showed more sensitivity than pAb-rVP2/mAb-VP2-13 at detecting low concentrations in a sample. Thus, it was hypothesized that the implications of $p A b s$, which can detect multiple epitopes simultaneously, may replace at least one mAb in the sandwich format of an IC test [32]. Furthermore, this design helps the antigen-pAb complex to react with mAb-rVP1-1 or mAb-rVP2-13 embedded at the test line, therefore enhancing the capturing specificity. In a preliminary test, an IC kit reacted negatively against deformed-wing virus (DWV)-infected adult bee samples. Thus, it is important to ensure that the capture antibody does not recognize other antigens present in a field sample. Currently, there is no commercially available IC test kit for the detection of AcSBV. 
The specificities and sensitivity of the newly developed test strips described in the present study are also comparable with the real-time PCR method.

RT-PCR is a simple, sensitive, and cost-effective method to detect SBV RNA based on the amplification of specific viral sequences $[9,23,27]$. However, this method is limited to quantifying viral RNA and often produces enormous specificity and sensitivity. Real-time RT-PCR is a better tool for sensitive, accurate, and specific detection and quantification of SBV $[25,26,29]$. Nevertheless, the two methods are time-consuming and require highly trained personnel to handle specialized laboratory instruments. RT-LAMP detected SBV RNA as soon as $20 \mathrm{~min}$ at $65^{\circ} \mathrm{C}$, and is suitable for onsite detection in field [24]. Although this method has some advantages, one of the limitations is a high risk of carryover contamination which often produces false-positive results in negative samples [52]. Compared with the traditional detection methods, an IC strip method has the advantages of being easy to use, providing an answer rapidly and at a low cost, and not requiring specialized equipment or technical personnel; thus, such a method is suitable for field testing for antigens.

\section{Conclusions}

This study established a basis for the development of related IC detection kits that are useful for bee farmers and verified their capability for rapidly diagnosis at the time and site of an encounter with environmental samples.

Supplementary Materials: The following are available online at https://www.mdpi.com/article/ $10.3390 / v 13122439 / \mathrm{s} 1$. Figure S1: (A) 10\% SDS-PAGE of the purified IgG from blood collected from wild-type mouse at the seventh week. (B) 10\% SDS-PAGE of the purified IgG (pAb-rVP1) from antiserum collected from rVP1-inmunized mouse at the seventh week (left) and Western blot analysis of the rVP1 using pAb-rVP1 (right). (C) 10\% SDS-PAGE of the purified IgG (pAb-rVP2) from antiserum collected from rVP2-inmunized mouse at the seventh week (left) and Western blot analysis of the rVP2 using pAb-rVP2 (right); Figure S2: Mouse intraperitoneal injected with hybridoma cells containing $\mathrm{mAb}-\mathrm{VP} 1$ and $\mathrm{mAb}-\mathrm{VP} 2$, respectively. Ascites formation and monoclonal antibody production was carried out in Freund's incomplete adjuvant-primed male mice (6-10 weeks old; $0.5 \mathrm{~mL} /$ mouse). Ascites fluid containing a high level of antibody was collected from each mouse at 10 days after inoculation. The animals usually survived 11-16 days after being injected with the tumor cells; Figure S3: Purified monoclonal IgG-VP1 and IgG-VP2 from ascites of mice which were injected with hybridoma cells containing $\mathrm{mAb}-\mathrm{VP} 1$ and $\mathrm{mAb}-\mathrm{VP} 2$, respectively; Figure S4: A ten-fold serial dilution series of the pET28a-VP1 and pET28a-VP2 ranging from $1 \times 10^{3}$ to $1 \times 10^{6}$ copies $/ \mu \mathrm{L}$, was used to construct the standard curves for both VP1 andVP2. Each standard dilution was amplified by real-time qPCR using primer sets of VP1 and VP2 in duplicate. The plot of a standard curve of $\mathrm{Ct}$ values against the logarithmic dilutions produced a regression line $(\mathrm{y}=-3.8356 \mathrm{x}+42.7930$, $\left.R^{2}=0.9965\right)$ for the VP1 (A) and a regression line $\left(y=-3.7314 x+43.5159, R^{2}=0.9933\right)$ for the VP2 (B). Figure S5: Sensitivity test of mAb-V1-1; and Figure S6: Specificity test of mAb-V1-1.

Author Contributions: S.H.L. and S.O. performed the experiment and analyzed the data; T.-K.O. prepared resources, performed the experiment, and conceptualized the project; S.K. and H.B.N. performed animal care and the experiment; N.V. edited the manuscript; J.Y.L. and E.S.M. prepared materials and methods for the experiments; and C.W.C. wrote the manuscript and performed funding acquisition for this project. All authors have read and agreed to the published version of the manuscript.

Funding: This work (grant no. C0531132) was supported by the project for Cooperative R\&D of the Industry, Academy, and Research Institute funded by the Korean Ministry of SMEs and Startups.

Institutional Review Board Statement: All animal procedures were approved by the Ethics Committee of Pai Chai University (PCU-2021-1).

Informed Consent Statement: Not applicable.

Acknowledgments: We greatly appreciate the peer reviewers for their kind and constructive comments to improve the quality of this manuscript. 
Conflicts of Interest: The authors declare no conflict of interest.

\section{References}

1. Ai, H.; Yan, X.; Han, R. Occurrence and prevalence of seven bee viruses in Apis mellifera and Apis cerana apiaries in China. J. Invertebr. Pathol. 2012, 109, 160-164. [CrossRef]

2. Forsgren, E.; Wei, S.; Guiling, D.; Zhiguang, L.; Tran, T.V.; Tang, P.T.; Truong, T.A.; Dinh, T.Q.; Fries, I. Preliminary observation on possible pathogen spill-over from Apis mellifera to Apis cerana. Apidologie 2015, 46, 265-275. [CrossRef]

3. Yanez, O.; Zheng, H.Q.; Su, X.L.; Hu, F.L.; Neumann, P.; Dietemann, V. Potential for virus transfer between the honey bees Apis mellifera and A. cerana. J. Apic. Res. 2015, 54, 179-191. [CrossRef]

4. Thu, H.T.; Lien, N.T.K.; Linh, M.T.; Le, T.H.; Hoa, N.T.; Thai, P.H.; Reddy, K.E.; Yoo, M.S.; Kim, Y.-H.; Cho, Y.S.; et al. Prevalence of bee viruses among Apis cerana population in Vietnam. J. Apic. Res. 2016, 55, 379-385. [CrossRef]

5. Li, Y.; Zeng, Z.J.; Wang, Z.L. Phylogenetic analysis of the honey bee scabrood virus. J. Apic. Sci. 2016, 60, 31-38.

6. Thai, P.H.; Huyen, N.T.; Toan, T.V.; Jung, C. Apis cerana beekeeping and sacbrood disease management in Vietnam: Review. J. Apic. 2018, 33, 269-275. [CrossRef]

7. Ko, C.-Y.; Chiang, Z.-L.; Liao, R.-J.; Chang, Z.-T.; Chang, J.-C.; Kuo, T.-Y.; Chen, Y.-W.; Nai, Y.-S. Dynamics of Apis cerana sacbrood virus (AcSBV) prevalence in Apis cerana (Hymenoptera: Apidae) in northern Taiwan and demonstration of its infection in Apis mellifera (Hymenoptera: Apidae). J. Econ. Entomol. 2019, 112, 2055-2066. [CrossRef] [PubMed]

8. Zhang, X. Managed honeybee colonies and honey production in China grew during the last five decades. J. Apic. Sci. 2011, 55, 77-85.

9. Choi, Y.S.; Lee, M.Y.; Hong, I.P.; Kim, N.S.; Kim, H.K.; Lee, K.G.; Lee, M.L. Occurrence of sacbrood virus in Korean apiaries from Apis cerana (Hymenoptera: Apidae). J. Apic. 2010, 25, 187-191.

10. Choe, S.E.; Nguyen, T.T.D.; Hyun, B.H.; Noh, J.H.; Lee, H.S.; Kang, S.W. Genetic and phylogenetic analysis of South Korean sacbrood virus isolates from infected honey bees (Apis cerana). Vet. Microbiol. 2012, 157, 32-40. [CrossRef]

11. Theisen-Jones, H.; Bienefeld, K. The Asian honey bee (Apis cerana) is significantly in decline. Bee World 2016, 93, 90-97. [CrossRef]

12. Vung, N.N.; Lee, M.-L.; Lee, M.-Y.; Kim, H.K.; Kang, E.J.; Kim, J.E.; Choi, Y.-S. Breeding and selection for resistance to sacbrood virus for Apis cerana. J. Apic. 2017, 32, 345-352. [CrossRef]

13. Procházková, M.; Füzik, T.; Škubnik, K.; Moravcová, J.; Ubiparip, Z.; Přidal, A.; Plevka, P. Virion structure and genome delivery mechanism of sacbrood honeybee virus. Proc. Natl. Acad. Sci. USA 2018, 115, 7759-7764. [CrossRef] [PubMed]

14. Roberts, J.M.K.; Anderson, D.L. A novel strain of sacbrood virus of interest to world apiculture. J. Invertebr. Pathol. 2014, 118, 71-74. [CrossRef]

15. Gong, H.-R.; Chen, X.-X.; Chen, Y.P.; Hu, F.-L.; Zhang, J.-L.; Lin, Z.-G.; Yu, J.-W.; Zheng, H.-Q. Evidence of Aphis cerana Sacbrrod virus infection in Apis mellifera. Appl. Environ. Microbiol. 2016, 82, 2256-2262. [CrossRef] [PubMed]

16. Aruna, R.; Srinivasan, M.R.; Balasubramanian, V.; Selvarajan, R. Complete genome sequence of sacbrood virus isolated from Asiatic honey bee Apis cerana indica in India. Virus Dis. 2018, 28, 453-460. [CrossRef]

17. Zhang, Y.; Zhang, G.; Huang, X.; Han, R. Proteomic analysis of Apis cerana and Apis mellifera larvae fed with heterospecific royal jelly and by CSBV challenge. PLoS ONE 2014, 9, e102663. [CrossRef]

18. Reddy, K.E.; Thu, H.T.; Yoo, M.S.; Ramya, M.; Reddy, B.A.; Lien, N.T.K.; Trang, N.T.P.; Duong, B.T.T.; Lee, H.-J.; Kang, S.-W.; et al. Comparative genomic analysis for genetic variation in Sacbrood virus of Apis cerana and Apis mellifera honeybees from different regions of Vietnam. J. Insect Sci. 2017, 17, 1-7. [CrossRef]

19. Li, J.; Wang, T.; Evans, J.D.; Rose, R.; Zhao, Y.; Li, Z.; Li, J.; Huang, S.; Heerman, M.; Rodríguez-García, C.; et al. The phylogeny and pathogenesis of Sacbrood virus (SBV) infection in European honey bees, Apis mellifera. Viruses 2019, 11, 61. [CrossRef]

20. Bostina, M. Monoclonal antibodies point to Achilles' heel in picornavirus capsid. PLoS Biol. 2019, 17, e3000232. [CrossRef]

21. Oh, S. Detection of sacbrood virus infecting Apis cerana (AcSBV) using polyclonal antibody raised against recombinant VP3 capsid protein expressed in Escherichia coli. J. Apic. 2019, 34, 149-156. [CrossRef]

22. Lee, J.-G.; Nguyen, P.V.; Soo, B.J.; Lim, H.-Y.; Yoon, B.-S. Detection of capsid protein of Sacbrood virus in honeybee using monoclonal antibodies. J. Apic. 2013, 28, 113-120.

23. Yan, X.; Chen, J.-H.; Han, R.-C. Detection of Chinese sacbrood virus (CSBV) in Apis cerana by RT-PCR method. Sociobiology 2009, 53, 687-694.

24. Yang, J.-L.; Yang, R.; Shen, K.-F.; Peng, X.-W.; Xion, T.; Liu, Z.-H. Rapid detection of sacbrood virus (SBV) by one-step reverse transcription loop-mediated isothermal amplification assay. Virol. J. 2012, 9, 47.

25. Kukielka, D.; Sanchez-Vizcaino, J.M. One-step real-time quantitative PCR for the detection and field study of Sacbrood honeybee and Acute bee paralysis viruses. J. Virol. Methods 2009, 161, 240-246. [CrossRef] [PubMed]

26. Thi, K.C.N.; Yoo, M.S.; Kang, M.H.; Han, S.H.; Yun, C.H.; Yoon, B.-S. Development of real time PCR assay for the detection of Sacbrood virus in honeybee (Apis mellifera L.). J. Apic. 2009, 24, 15-21.

27. Rana, R.; Rana, B.S.; Kaushal, N.; Kumar, D.; Kaundal, P.; Khan, M.A.; Gwande, S.J.; Sharma, H.K. Identification of sacbrood virus disease in honeybee, Apis mellifera L. by using ELISA and RT-PCR techniques. Indian J. Biotechnol. 2011, 10, $274-284$.

28. Yoo, M.-S.; Thi, K.C.N.; Van Nguyen, P.; Han, S.-H.; Kwon, S.-H.; Yoon, B.S. Rapid detection of sacbrood virus in honeybee using ultra-rapid real-time polymerase chain reaction. J. Virol. Methods 2012, 179, 195-200. [CrossRef] 
29. Zhang, Y.; Huang, X.; Xu, Z.F.; Han, R.C.; Chen, J.H. Differential gene transcription in honeybee (Apis cerana) larvae challenged by Chinese sacbrood virus (CSBV). Sociobiology 2013, 60, 413-420. [CrossRef]

30. McMenamin, A.J.; Flenniken, M.L. Recently identified bee viruses and their impact on bee pollinators. Curr. Opin. Insect Sci. 2018, 26, 120-129. [CrossRef]

31. Jain, J.; Okabayashi, T.; Kaur, N.; Nakayama, E.; Shioda, T.; Gaind, R.; Kurosu, T.; Sunil, S. Evaluation of an immunochromatography rapid diagnosis kit for detection of chikungunya virus antigen in India, a dengue-endemic country. Virol. J. 2018, 15, 84. [CrossRef] [PubMed]

32. Sharma, C.; Singh, M.; Upmanyu, V.; Chander, V.; Verma, S.; Chakrovarty, S.; Sharma, G.K.; Dhanze, H.; Singh, P.; Shrivastava, S.; et al. Development and evaluation of a gold nanoparticle-based immunochromatographic strip test for the detection of canine parvovirus. Arch. Virol. 2018, 163, 2359-2368. [CrossRef] [PubMed]

33. Yu, S.-T.; Bui, C.T.; Kim, D.T.H.; Nguyen, A.V.T.; Trinh, T.T.T.; Yeo, S.-J. Clinical evaluation of rapid flurescent diagnostic immunochromatographic test for influenza A virus (H1N1). Sci. Rep. 2018, 8, 13468. [CrossRef] [PubMed]

34. Wang, S.; Wen, Y.; An, T.; Duan, G.; Sun, M.; Ge, J.; Li, X.; Yang, K.; Cai, X. Development of an immunochromatographic strip for rapid detection of canine adenovirus. Front. Microbiol. 2019, 10, 2882. [CrossRef]

35. Yale, G.; Ginson, A.D.; Mani, R.S.; Harsha, P.K.; Costa, N.C.; Corfmat, J.; Otter, I.; Otter, N.; Handel, I.G.; Bronsvoort, B.M.; et al. Evaluation of an immunochromatographic assay as a canine rabies surveillance tool in Goa, India. Viruses 2019, 11, 649. [CrossRef]

36. Wang, X.-L.; Wang, L.; Hasi, C.-L.; Wang, Y.-P.; Khan, A.; Ren, B.-Z.; Liu, Z.-Z.; Hou, S.-L.; Yang, L.-H.; Zhang, L.-Y.; et al. A rapid colloidal gold immunochromatographic assay for the diagnosis of coronavirus disease 2019. Chin. Med. J. 2020, 133, 1986-1988. [CrossRef]

37. Janwan, P.; Intapan, P.M.; Sadaow, L.; Rodpai, R.; Yamasaki, H.; Boonroumkaew, P.; Sanpool, O.; Thanchomnang, T.; Sadee, P.; Maleewong, W. Development of immunochromatographic test kit for rapid detection of specific IgG4 antibody in whole-blood samples for diagnosis of human gnathostomiasis. Diagnostics 2021, 11, 862. [CrossRef] [PubMed]

38. Shao, X.-Y.; Wang, C.-R.; Xie, C.-M.; Wang, X.-G.; Liang, R.-L.; Xu, W.-W. Rapid and sensitive lateral flow immunoassay method for procalcitonin (PCT) based on time-resolved immunochromatography. Sensor 2017, 17, 480. [CrossRef]

39. Ge, W.; Suryoprabowo, S.; Wu, X.; Zheng, Q.; Kuang, H. Rapid immnochromatographic test strip detection of mabuterol and its cross-reactivity with mapenterol. Food Agric. Immunol. 2018, 29, 1028-1040. [CrossRef]

40. Chen, Y.; Zhang, L.; Xu, L.; Guo, X.; Yang, H.; Zhuang, L.; Li, Y.; Wang, Z.; Gu, B. Rapid and sensitive detection of Shigella flexneri using fluorescent microspheres as label for immunochromatographic test strip. Ann. Transl. Med. 2019, 7, 565. [CrossRef]

41. Moongkarndi, P.; Rodpai, E.; Kanarat, S. Evaluation of an immunochromatographic assay for rapid detection of Salmonella enterica serovars Typhimurium and Enteritidis. J. Vet. Diagn. Investig. 2011, 23, 797-801. [CrossRef] [PubMed]

42. Evangelista, V.O.; Pelegrini, P.B.; Mulinari, F.; de Moura, R.; Cardoso, L.P.V.; Bührer-Sékula, S.; Miller, R.; Pinto, E.R.; Grossi-de-Sá, M.F. A novel immunochromatographic strip test for rapid detection of Cry1Ac and Cry8Ka5 proteins in genetically modified crops. Anal. Methods 2015, 7, 9331.

43. Isanga, J.; Tochi, B.N.; Mukunzi, D.; Chen, Y.; Liu, L.; Kuang, H.; Xu, C. Development of a specific monoclonal antibody assay and a rapid testing strip for the detection of apramycin residues in food samples. Food Agric. Immunol. 2017, 28, 49-66. [CrossRef]

44. Qriouet, Z.; Cherrah, Y.; Sefrioui, H.; Qmichou, Z. Monoclonal antibodies application in lateral flow immunochromatographic assays for drugs of abuse detection. Molecules 2021, 26, 1058. [CrossRef] [PubMed]

45. Wang, R.; Zhang, W.; Wang, P.; Su, X. A paper-based competitive lateral flow immunoassay for multi $\beta$-agonist residues by using a single monoclonal antibody labelled with red fluorescent nanoparticles. Microchim. Acta 2018, 185, 191. [CrossRef]

46. Zeng, L.; Song, S.; Zheng, Q.; Luo, P.; Wu, X.; Kuang, H. Development of a sandwich ELISA and immunochromatographic strip for the detection of shrimp tropomyosin. Food Agric. Immunol. 2019, 30, 606-619. [CrossRef]

47. Liu, I.-L.; Lin, Y.-C.; Lin, Y.-C.; Jian, C.-Z.; Cheng, I.C.; Chen, H.-W. A novel immunochromatographic strip for antigen detection of avian infectious bronchitis virus. Int. J. Mol. Sci. 2019, 20, 2216. [CrossRef]

48. Lee, C.; Kim, J.; Shin, S.G.; Hwang, S. Absolute and relative QPCR quantification of plasmid copy number in Escherichia coli. J. Biotechnol. 2006, 123, 273-280. [CrossRef]

49. Fei, D.; Zhang, H.; Diao, Q.; Jiang, L.; Wang, Q.; Zhong, Y.; Fan, Z.; Ma, M. Codon optimization, expression in Escherichia coli, and immunogenicity of recombinant Chinese sacbrood virus (CSBV) structural proteins VP1, VP2, VP3. PLoS ONE 2015, 10, e0128486. [CrossRef]

50. Kantere, M.C.; Athanasiou, L.V.; Spyrou, V.; Kyriakis, C.S.; Kontos, V.; Chatzopoulos, D.C.; Tsokana, C.N.; Billinis, C. Diagnostic performance of a rapid in clinic test for the detection of Canine Parvovirus under different storage conditions and vaccination status. J. Virol. Methods 2015, 215, 52-55. [CrossRef]

51. Cepica, A.; Yason, C.; Ralling, G. The use of ELISA for detection of the antibody induced conformational change in a viral protein and its intermolecular spread. J. Virol. Methods 1990, 28, 1-14. [CrossRef]

52. Wong, Y.-P.; Othman, S.; Lau, Y.-L.; Radu, S.; Chee, H.-Y. Loop-mediated isothermal amplification (LAMP): A versatile technique for detection of micro-organism. J. Appl. Microbiol. 2018, 124, 626-643. [CrossRef] [PubMed] 